\title{
シクラメン野生種における体細胞胚形成
}

\author{
古川一実・柿原文香・加藤正弘 \\ 愛媛大学農学部植物育種学研究室 790-8566 愛媛県松山市樽味 3-5-7
}

\section{Somatic Embryogenesis in Seven Wild Cyclamen Species}

\author{
Kazumi Furukawa, Fumika KaKiHara and Masahiro Kato \\ Laboratory of Plant Breeding, Faculty of Agriculture, Ehime University, 3-5-7 \\ Tarumi, Matsuyama, Ehime 790-8566, Japan
}

\begin{abstract}
Embryogenesis in seven Cyclamen species, i. e. C. cilicium, C. coum, C. graecum, C. hederifolium, $C$. persicum, $C$. purpurascens, and $C$. rohlfsianum was investigated by using petioles and leaves of mature plants as explants. Two culture protocols were used for callus induction: 1 ) Linsmaier and Skoog (LS) medium containing $1.0 \mathrm{mg} \cdot l^{-1} 2,4-\mathrm{D}, 0.1 \mathrm{mg} \cdot l^{-1}$ kinetin, $50.0 \mathrm{~g} \cdot$ $l^{-1}$ sucrose, and $2.0 \mathrm{~g} \cdot l^{-1}$ gellan gum, and 2) Modified Murashige and Skoog (MS) medium containing $5.0 \mathrm{mg} \cdot l^{-1} 2,4-\mathrm{D}, 0.1 \mathrm{mg} \cdot l^{-1}$ kinetin, $60.0 \mathrm{~g} \cdot l^{-1}$ sucrose, and $3.0 \mathrm{~g} \cdot l^{-1}$ gellan gum. Callus was initially formed in all species from both petiole and leaf explants, excluding the leaf explants of $C$. hederifolium and $C$. coum. Cyclamen cilicium showed a low callusing rate, and produced somatic embryos on both callus induction media. After callus multiplication, the calli were transferred into medium, excluding the plant growth regulators, to induce somatic embryos. Somatic embryos were induced in C. cilicium, C. coum, C. graecum and C. rohlfsianum; unipolar tuber-like bodies were formed in $C$. purpurascens through shaking the culture; and adventitious roots were produced in C. persicum. Somatic embryogenesis and organogenesis were not observed from the calli of C. hederifolium. In C. graecum and C. coum, somatic embryos were induced in liquid media, and the embryos of $C$. graecum developed like microtubers. In $C$. purpurascens, unipolar tuber-like bodies were formed from compact calli, but did not grow into plantlets. Induction of somatic embryogenesis was successful in 4 Cyclamen species. The outcomes of this study demonstrate that micropropagation through somatic embryogenesis is possible in some Cyclamen species.
\end{abstract}

Keywords : Cyclamen, in vitro preservation, somatic embryogenesis, callus, tissue culture, microtuber.

\section{緒言 \\ サクラソウ科シクラメン属 (Cyclamen) には 20 種が存 在し, フランス南西部から地中海沿岸にかけて自生して いる1). 鉢物として重要なシクラメンの園芸品種は, Cyclamen persicum 1 種のみの種内交雑と変異から成立}

2001 年 6 月 11 日受付

2001 年 9 月 5 日受理
したとされている.一方, シクラメンの野生種は, 園芸 品種にはない耐寒性, 秋咲き性, 耐病性などの形質や, 園芸品種とは異なる特徴的な芳香性や葉の形を有し, 今 後のシクラメンの改良に重要な遺伝資源である. 実際に, 野生種と園芸品種との交雑による種間雑種作出が成功し ており ${ }^{1 \sim 5)}$ ，ますます今後のシクラメンの改良に野生種 が使われることが推察される。しかしながら野生種は, 開発による自生地の減少や乱獲のため絶滅の危機にさら されており, ワシントン条約で国際的な商取引を規制さ れた希少植物でもある1).さらにはシクラメンの繁殖様 
式は種子繁殖であり，自然状態では株分けや挿し木，分 球といった栄養繁殖は起こらない. また，中には難結実 性を示す種も存在するため，その保全は必要に迫られて いる.よって, シクラメン野生種の遺伝資源の保全と優 良個体の増殖のためには組織培養による大量増殖法が有 効であると考えられる.

近年, 成功しているシクラメン園芸品種の組織培養に は大きく分けて二つの手法が用いられている.一つは不 定芽による増殖法6 13)であり，もう一つは体細胞胚誘導 による増殖法である ${ }^{8,14 \sim 19)}$. 中でも体細胞肧増殖では Kreuger ら (1995) ${ }^{20)}$ や Wilnkelmann 培養による大量増殖も可能であることを報告している. 一方, シクラメン野生種の組織培養に関する報告は Karam and Al-Majathoub $(2000)^{22)}$ が野生種の C. persicum の不定芽を誘導したもののみであり，これまでの 研究対象は園芸品種がほとんどであった。よって, 筆者 らはシクラメン野生種を対象に, 不定芽形成よりも大量 増殖が可能なこと, および植物体形成が簡便であること から，体細胞胚誘導を試みた。 その結果，本実験におい ていくつかの野生種で体細胞胚の形成が初めて認められ た事を報告する。

\section{材料および方法}

\section{1. 材 料}

愛媛大学農学部ガラス温室で育成しているシクラメン 野生種 7 種の成株を供試材料に用いた (Table 1).

\section{2. 外植体の滅菌}

外植体には，成株の葉柄および葉身を用いた，前処理 として雑菌污染抑制のために硝酸銀処理を行った. 展開
葉を摘出し，葉柄の基部を $2.0 \mathrm{~g} \cdot l^{-1}$ 硝酸銀水溶液に浸 し 16 時間吸水させた. その後, 葉全体の表面殺菌とし て $70 \%$ エタノール中に 30 秒間浸した後, $64.0 \mathrm{~g} \cdot l^{-1}$ 次 亜塩素酸カルシウム溶液(有効塩素 3.8～4.5\%) に展着剂 (ヤマト展着剤) を数滴加えたもので 15 分間殺菌した. 滅菌水で 3 回すすいだ後にクリーンベンチ内で葉柄およ び葉身をそれぞれ, $5 \mathrm{~mm}, 5 \times 5 \mathrm{~mm}$ に切断し外植体と した.

\section{3. カルスおよび体細胞胚誘導}

カルスおよび体細胞肧誘導のいずれにおいても, 培地 はすべて $50 \mathrm{~m} l$ の UM サンプル瓶(柏洋硝子株式会社) に $20 \mathrm{ml}$ ずつ分注し, アルミホイルでキャップした. 液 体培養は, gellan gum 除いた培地を $20 \mathrm{~m} l$ 分注した $50 \mathrm{~m} l$ の三角フラスコを用いて 80 r. p. m.の水平回転円 振とうにて行った. 培地のpHはオートクレーブ前に 5.8 に調節した.オートクレーブ条件は $120^{\circ} \mathrm{Cで} 20$ 分間, 1 気圧下とした。培養は特に記載のない限り $20^{\circ} \mathrm{C}$, 暗黒 下で行い, 継代は 40〜50 日間隔で行った。

カルス誘導には次の二つの培地（LS培地および修正 MS 培地）を用いた。

\section{(1) LS 培地}

Linsmaier and Skoog $(1965)^{23)}$ の培地に $1.0 \mathrm{mg} \cdot l^{-1}$ 2, 4-dichlorophenoxyacetic acid $(2,4-\mathrm{D}), 0.1 \mathrm{mg} \cdot l^{-1}$ kinetin, $50.0 \mathrm{~g} \cdot l^{-1}$ sucrose, および $2.0 \mathrm{~g} \cdot l^{-1}$ gellan gumを添加したものを用いた(Otani and Shimada, 1991) ${ }^{14)}$.

\section{（2）修正 MS 培地}

Murashige and Skoog (1962) ${ }^{24)}$ の培地の主成分のう ち, $\mathrm{NH}_{4} \mathrm{NO}_{3}, \mathrm{KNO}_{3}, \mathrm{CaCl}_{2} \cdot 2 \mathrm{H}_{2} \mathrm{O}, \mathrm{MgSO}_{4} \cdot 7 \mathrm{H}_{2} \mathrm{O}$ およ び $\mathrm{KH}_{2} \mathrm{PO}_{4}$ の濃度を半分にした修正 MS培地に5.0

表 1 供試材料

Table 1 Plant materials

\begin{tabular}{|c|c|c|}
\hline Species & Source & No. of plants \\
\hline Cyclamen cilicium & Yoshioka Nursery (Japan) & 2 \\
\hline C. coum & Ashwood Nurseries (U. K.) & 1 \\
\hline \multirow[t]{2}{*}{ C. graecum } & Hiroshima Botanical Garden (Japan) & 1 \\
\hline & Saitama Agr. Forest. Res. Cen. ${ }^{1)}$ & 1 \\
\hline \multirow[t]{3}{*}{ C. hederifolium } & Hiroshima Botanical Garden (Japan) & 1 \\
\hline & Garden Bureau ${ }^{2)}$ & 1 \\
\hline & Yoshioka Nursery (Japan) & 2 \\
\hline C. persicum & Kazuo Mori & 1 \\
\hline \multirow[t]{2}{*}{ C. purpurascens } & Ashwood Nurseries (U. K.) & 2 \\
\hline & Yoshioka Nursery (Japan) & 2 \\
\hline \multirow[t]{2}{*}{ C. rohlfsianum } & Hiroshima Botanical Garden (Japan) & 1 \\
\hline & Saitama Agr. Forest. Res. Cen. & 1 \\
\hline
\end{tabular}


$\mathrm{mg} \cdot l^{-1} 2,4-\mathrm{D}, 0.1 \mathrm{mg} \cdot l^{-1}$ kinetin, $60.0 \mathrm{~g} \cdot l^{-1}$ sucrose, $3.0 \mathrm{~g} \cdot l^{-1}$ gellan gum および $10.0 \%(\mathrm{v} / \mathrm{v})$ ココナッツミ ルクを添加したものを用いた.ココナッツミルク（輸入 元：有紀トレーディング株式会社)はSterivex ${ }^{\mathrm{TM}-\mathrm{GV}}$ (Millipore $0.22 \mu \mathrm{m}$ Filter Unit)により吸引濾過滅菌し た後, オートクレーブ滅菌の後の培地に無菌的に添加し た.

カルスは，体細胞胚誘導培地に移植し体細胞胚形成を 促した。体細胞肧誘導培地には，上記の 2 種類のカルス 誘導培地からそれぞれ植物成長調節物質を除いた固形培 地および液体培地を用いた。なお，得られたカルスには 不定根を形成したカルスも認められたが，用いるカルス の状態を均一にするため, 体細胞肧誘導には供試しなか った.

\section{4. 植物体育成}

体細胞胚を，修正 MS 培地に $30.0 \mathrm{~g} \cdot l^{-1}$ sucrose お子
よび $3.0 \mathrm{~g} \cdot l^{-1}$ gellan gum を添加した培地に移植し, $25^{\circ} \mathrm{C}$, 約 $1600-2000 \operatorname{lux}$ (光合成光量子束密度 $20 \sim 30$ $\mu \mathrm{mol} / \mathrm{m} / \mathrm{s}$ )の蛍光灯照明下で 16 時間日長で培養した。

\section{5. 組織学的観察}

パラフィン切片法により, 組織学的観察を行った。体 細胞胚を FAA (37\% formaldehyde solution : $80 \%$ ethanol : acetic acid, $1: 8: 1, \mathrm{v} / \mathrm{v})$ で固定した後, アルコー ルシリーズで脱水し，パラフィン中に包埋した。 パラフ イン試料をミクロトームで厚さ $20 \mu \mathrm{m}$ の連続切片にし, Heidenhein の鉄みょうばんへマトキシリン染色法によ り染色した後, 光学䫒微鏡下で観察した.

\section{結果および考察}

\section{1. カルス誘導}

7 種のシクラメン野生種について, 成株の葉柄および

表 2 シクラメン野生種における葉柄および葉身からのカルス形成

Table 2 Callus formation from petiole and leaf explants in Cyclamen wild species

\begin{tabular}{|c|c|c|c|c|c|c|c|}
\hline $\begin{array}{l}\text { Type of } \\
\text { explant }\end{array}$ & Species & Medium & $\begin{array}{l}\text { No. of } \\
\text { explants } \\
\text { inoculated }\end{array}$ & $\begin{array}{l}\text { No. of } \\
\text { explants } \\
\text { contaminated }\end{array}$ & $\begin{array}{l}\text { No. of } \\
\text { healthy } \\
\text { explants } \\
\text { (a) }\end{array}$ & $\begin{array}{l}\text { No. of } \\
\text { explants } \\
\text { forming } \\
\text { callus } \\
\quad \text { (b) }\end{array}$ & $(\mathrm{b} / \mathrm{a})$ \\
\hline \multirow[t]{14}{*}{ Petiole } & \multirow[t]{2}{*}{ C. cilicium } & LS & 86 & 19 & 67 & 19 & 28.4 \\
\hline & & Modified MS & 74 & 0 & 74 & 13 & 17.6 \\
\hline & \multirow[t]{2}{*}{ C. coum } & LS & 72 & 0 & 72 & 59 & 81.9 \\
\hline & & Modified MS & 54 & 9 & 45 & 41 & 91.1 \\
\hline & \multirow[t]{2}{*}{ C. graecum } & LS & 109 & 9 & 100 & 74 & 74.0 \\
\hline & & Modified MS & 84 & 8 & 76 & 48 & 63.2 \\
\hline & \multirow[t]{2}{*}{ C. hederifolium } & LS & 178 & 29 & 149 & 2 & 1.3 \\
\hline & & Modified MS & 187 & 121 & 66 & 25 & 37.9 \\
\hline & \multirow[t]{2}{*}{ C. persicum } & LS & 35 & 0 & 35 & 34 & 97.1 \\
\hline & & Modified MS & 34 & 13 & 21 & 21 & 100.0 \\
\hline & \multirow[t]{2}{*}{ C. purpurascens } & LS & 144 & 44 & 100 & 69 & 69.0 \\
\hline & & Modified MS & 147 & 40 & 107 & 57 & 53.3 \\
\hline & \multirow[t]{2}{*}{ C. rohlfsianum } & LS & 78 & 21 & 57 & 45 & 78.9 \\
\hline & & Modified MS & 73 & 9 & 64 & 51 & 79.7 \\
\hline \multirow[t]{14}{*}{ Leaf } & \multirow[t]{2}{*}{ C. cilicium } & LS & 107 & 5 & 102 & 4 & 3.9 \\
\hline & & Modified MS & 107 & 21 & 86 & 3 & 3.5 \\
\hline & \multirow[t]{2}{*}{ C. coum } & LS & 99 & 0 & 99 & 0 & 0.0 \\
\hline & & Modified MS & 57 & 1 & 56 & 52 & 92.9 \\
\hline & \multirow[t]{2}{*}{ C. graecum } & LS & 232 & 72 & 160 & 83 & 51.9 \\
\hline & & Modified MS & 208 & 148 & 60 & 48 & 80.0 \\
\hline & \multirow[t]{2}{*}{ C. hederifolium } & LS & 231 & 24 & 207 & 0 & 0.0 \\
\hline & & Modified MS & 227 & 95 & 132 & 0 & 0.0 \\
\hline & \multirow[t]{2}{*}{ C. persicum } & LS & 48 & 4 & 44 & 21 & 47.7 \\
\hline & & Modified MS & 48 & 5 & 43 & 31 & 72.1 \\
\hline & \multirow[t]{2}{*}{ C. purpurascens } & LS & 236 & 110 & 126 & 70 & 55.6 \\
\hline & & Modified MS & 216 & 162 & 54 & 19 & 35.2 \\
\hline & \multirow[t]{2}{*}{ C. rohlfsianum } & LS & 108 & 0 & 108 & 89 & 82.4 \\
\hline & & Modified MS & 108 & 108 & 0 & 0 & - \\
\hline
\end{tabular}



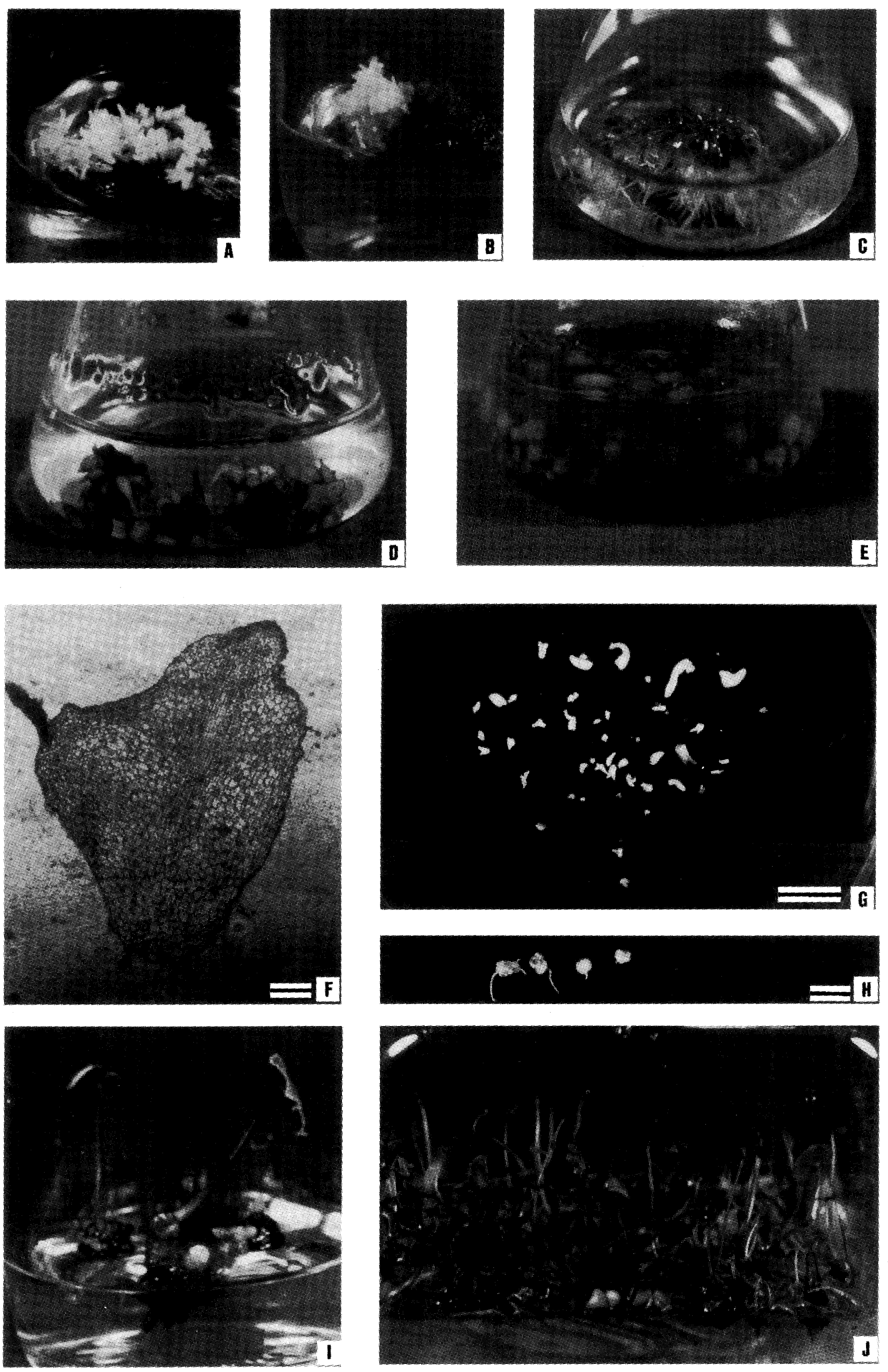
図 1 (A) 修正 MS 培地上での C. cilicium の葉柄由来カルスからの体細胞胚形成 (B) LS ホルモンフリー培地上での $C$. graecum の葉柄由来カルスからの体細胞胚形成 (C) LS 液体培地中に抢けるC. persicum の不定根形成 (D) LS 液体培地中における . purpurascens の葉身由来カルスからの一極性塊茎様体形成（E) LS 液体培地中に抢けるC. graecum のマイクロチューバー状に肥大した体細胞胚 (F) C. graecum (20 $\mu \mathrm{m}$ 切片)の早期心臟型胚様の体細胞胚 $\mathrm{Bar}=40 \mu \mathrm{m} \quad$ (G) C. cilicium から誘導された様々なステージの体細胞胚 Bar $=1 \mathrm{~cm} \quad(\mathrm{H})$ 芽と根を持つマイクロチ ューバー状に成長した C. graecum の体細胞胚 Bar $=1 \mathrm{~cm} \quad$ (I)マイクロチューバー状に成長した C. graecum の体細 胞肧からの植物体形成 (J)C. cilicium の体細胞胚からの植物体形成

Fig. 1 (A) Somatic embryos derived from the petiole explant of C. cilicium on the modified MS medium. (B) Somatic embryos derived from the petiole explant of C. graecum on the LS medium. (C) Adventitious roots from the explants of $C$. persicum in the LS liquid medium (somatic embryo-induction medium). (D) Unipolar tuber-like bodies derived from the leaf explants of $C$. purpurascens in the LS liquid medium. (E) Microtubers derived from the somatic embryos of $C$. graecum on the LS medium. (F) An early heart shaped somatic embryo of C. graecum ( $20 \mu \mathrm{m}$ section). Bar $=40 \mu \mathrm{m}$ (G) Various ages of somatic embryos of $C$. cilicium. Bar $=1 \mathrm{~cm} \quad$ (H) Somatic embryos of $C$. graecum grown like microtubers have both buds and roots in the liquid culture. $B a r=1 \mathrm{~cm}$ (I) Plantlets from somatic embryos of C. graecum grown like microtubers on the modified MS liquid medium. (J) Plantlets from the somatic embryos of $C$. cilicium on the modified MS solid medium.

葉身の切片から LS 培地と修正 MS 培地の 2 種類の培地 を用いてカルスを誘導した。 カルス形成は早いもので置 床 10 日目から見られた。 カルス形成率は種により様久 であった(Table 2)。ほとんどの種で，葉身よりも葉柄 で高いカルス形成率が認められた。 C. hederifolium は 他種と比較して明らかに低いカルス形成率を示した。

C. hederifolium およびC. coum の葉身を LS 培地で培 養した場合, 外植体はすべて褐変枯死した。しかし, C. coum においては，そのほかの区では 80-90\%のカ ルス形成率を示した。この様な培地間における大きな差 異は C. coum のみで見られた. 形成されたカルスの形 態は種により様々で，褐色，黄色，白色もしくは透明を 呈し, カルスの質も硬質なものや水浸状のもの, もしく はもろく崩れ易い，いわゆるフライアブル(friable)な ものが認められた。 また，C. persicum のカルスのほと んぞは継代培養中に不定根を旺盛に形成した。これらの 結果は種に特異的な傾向であることが推察される。

以前よりシクラメンの組織培養において内生菌による 雑菌污染が問題視されている ${ }^{6,10,11,19,25)}$. 本実験において も例外ではなく，バクテリアとカビによる両方の污染が 生じた。硝酸銀処理を施したにもかかわらず数種のシク ラメンの初代培養において高い雑菌污染が生じ, 特に葉 身で多発した，成株を材料に用いたときの有効な雑菌污 染防止策として黄化葉柄の利用が報告されている ${ }^{11,199}$. 本実験では材料の都合上行えなかったが，高い雑菌污染 率を考慮すると，今後適用していく必要があると考えら れる。

\section{2. 体細胞胚誘導過程における形態形成}

得られた葉柄および葉身由来のカルスを，植物成長調
節物質を除いた体細胞肧誘導培地に移植した。その結果， （1）体細胞肧は C. cilicium, C. coum, C. graecum，およ びC. rohlfsianum に扔いて形成され，(2) 一極性塊茎 様体の形成が $C$. purpurascens のカルスにおいて見られ， （3）不定根の形成は C. persicum および C. coum にお いて見られた。（4）C. hederifolium では体細胞胚形成 などの形態形成は全く観察されず，カルスも増殖しなか った.

\section{（1）体細胞胚の形成}

体細胞胚形成が見られたいずれの種においても，フラ イアブルなカルスが黒変化し表面に多数の球状の白い構 造物を形成した (Fig. 1A，B)。また，液体培地中では培 地が赤色に濁り多数の球状の白い構造物が浮遊していた。 これらの構造物はカルスからピンセットで容易に単離で き, また, パラフィン切片法を用いた組織学的観察から カルスとの維管束による連絡は無かった. 加えて種子胚 に似た構造をしており体細胞胚であることを確認した (Fig. 1F, G). よって, 透明あるいは褐色でフライアブ ルな形状のカルスは，体細胞胚を形成する，いわゆるエ ンブリオジェニックカルスであることが確認された。こ の結果は Otani and Shimada(1991) ${ }^{14)}$ の記述している 園芸品種 ‘テーブル ミニライラックローズ’における 葉身由来のエンブリオジェニックカルスの形態と同様で あった。

C. cilicium から形成されたフライアブルなカルスは あまり増殖せず小さいままであったが，カルス誘導培地 上で，36日目に体細胞胚を形成した (Fig. 1A)。体細胞 肧を形成したのは葉柄由来のカルスで LS，修正 MS 両 方の培地上であった，カルス誘導培地上で体細胞肧を形 
表 3 シクラメン野生種における葉柄由来カルスからの体細胞肧誘導

Table 3 Somatic embryogenesis from petiole callus of wild Cyclamen species

\begin{tabular}{|c|c|c|c|c|c|c|}
\hline Culture method & Species & Medium & $\begin{array}{l}\text { No. of } \\
\text { inoculated } \\
\text { calli }\end{array}$ & $\begin{array}{l}\text { No. of calli } \\
\text { producing } \\
\text { somatic } \\
\text { embryo }\end{array}$ & $\begin{array}{l}\text { No. of calli } \\
\text { producing } \\
\text { unipolar } \\
\text { tuber-like body }\end{array}$ & $\begin{array}{l}\text { No. of } \\
\text { calli } \\
\text { rooted }\end{array}$ \\
\hline \multirow{13}{*}{ Static culture } & \multirow{2}{*}{ C. cilicium } & LS & 12 & 5 & 0 & 1 \\
\hline & & Modified MS & 6 & 6 & 0 & 0 \\
\hline & \multirow[t]{2}{*}{ C. coum } & LS & 11 & 0 & 0 & 0 \\
\hline & & Modified MS & 15 & 0 & 0 & 5 \\
\hline & \multirow[t]{2}{*}{ C. graecum } & LS & 16 & 2 & 0 & 5 \\
\hline & & Modified MS & 23 & 11 & 0 & 2 \\
\hline & C. hederifolium & Modified MS & 16 & 0 & 0 & 0 \\
\hline & \multirow[t]{2}{*}{ C. persicum } & LS & 4 & 0 & 0 & 2 \\
\hline & & Modified MS & 14 & 0 & 0 & 3 \\
\hline & \multirow[t]{2}{*}{ C. purpurascens } & LS & 25 & 0 & 2 & 9 \\
\hline & & Modified MS & 21 & 0 & 0 & 2 \\
\hline & \multirow[t]{2}{*}{ C. rohlfsianum } & LS & 9 & 0 & 0 & 4 \\
\hline & & Modified MS & 20 & 1 & 0 & 0 \\
\hline \multirow[t]{10}{*}{ Liquid culture } & C. cilicium & LS & 1 & 0 & 0 & 0 \\
\hline & C. coum & Modified MS & 3 & 1 & 0 & 0 \\
\hline & \multirow[t]{2}{*}{ C. graecum } & LS & 12 & 1 & 0 & 0 \\
\hline & & Modified MS & 25 & 17 & 0 & 2 \\
\hline & \multirow[t]{2}{*}{ C. persicum } & LS & 2 & 0 & 0 & 0 \\
\hline & & Modified MS & 6 & 0 & 0 & 2 \\
\hline & \multirow[t]{2}{*}{ C. purpurascens } & LS & 12 & 0 & 1 & 1 \\
\hline & & Modified MS & 7 & 0 & 1 & 0 \\
\hline & \multirow[t]{2}{*}{ C. rohlfsianum } & LS & 2 & 0 & 0 & 0 \\
\hline & & Modified MS & 3 & 0 & 0 & 0 \\
\hline
\end{tabular}

成したのはこの種のみであった. カルスをホルモンフリー に移植した場合も多数の体細胞胚を形成した(Table 3, 4). C. cilicium はカルス形成率は低いが, 体細胞胚形 成率は高いといえる。

C. graecum ではカルス移植後 1 から 2 ケ月目にかけ て LS および修正 MS の両方の培地において体細胞胚を 形成した(Table 3, Fig. 1B). 液体培地中で得られた体 細胞胚は肥大し, 球状のマイクロチューバー状の形態を 呈し(Fig. 1E) やがて芽と根の原基を形成した(Fig. 1H). 前述の C. cilicium の固形培地で得られた体細胞胚を液 体培地に移植して水平円振とうを行っても二次肧の形成 のみでこのような肥大は見られなかった．C. graecum で得られたマイクロチューバー状形態形成は, 小林 $(1992)^{26)}$ により誘導されたシクラメン園芸品種 ‘ピュア ホワイト’の二極性の塊茎様体と形態的に良く類似して いた.この塊茎様体形成について小林 $(1992)^{26)}$ は, 培地 中のオーキシンレベルの緩やかな低下によって不完全な 体細胞胚誘導系となり, 最終的な形成体として塊茎様体 が形成されたと考察している. 本実験の C. graecum に おいてはオーキシンの存在するカルス誘導培地からホル モンフリーである体細胞肧誘導培地へ移植したときに,
なんらかの種特異的なホルモン減少への反応があったと 考えられる.

C. rohlfsianum では, 移植後 5 ヶ月目に固形培地上で 体細胞胚の形成が認められた (Table 3). C. coumでは, カルス移植後約 9 ヶ月目に液体培地中で体細胞胚形成が わずかに認められた. しかし，固形培地に移植しても体 細胞胚は芽や根を形成するに至らなかった (Table 3).

\section{（2）－極性塊茎様体の形成}

C. purpurascens においては体細胞胚誘導培地に移植 して 16 日目より硬質のカルスが黒変化し, カルスの表 面に白色の塊茥に似た構造物を形成した(Table 3, 4, Fig. 1D). この構造物は前述の体細胞胚とは明確に異な っており，カルスと接着した基部が肥大している外見か ら一極性塊茎様体と称した.これらは，カルスと連結し ていたため分離することは困難であった．また，植物体 育成用の固形培地に移植しても不定根の形成のみで植物 体へは至らなかった.

こういつた構造物については, 高村ら $(1995)^{12)}$ も園芸 品種から形成された「シュートあるいは体細胞胚とはや や外見が異なる塊茎様塊体」の形成を報告している。 た, Wicart ら ${ }^{8)}$ の実験においても一極性の塊茎様体や 
表 4 シクラメン野生種における葉身由来カルスからの体細胞胚誘導

Table 4 Somatic embryogenesis from leaf callus of wild Cyclamen species

\begin{tabular}{|c|c|c|c|c|c|c|}
\hline Culture method & Species & Medium & $\begin{array}{l}\text { No. of } \\
\text { inoculated } \\
\text { calli }\end{array}$ & $\begin{array}{l}\text { No. of calli } \\
\text { producing } \\
\text { somatic } \\
\text { embryo }\end{array}$ & $\begin{array}{l}\text { No. of calli } \\
\text { producing } \\
\text { unipolar } \\
\text { tuber-like body }\end{array}$ & $\begin{array}{l}\text { No. of } \\
\text { calli } \\
\text { rooted }\end{array}$ \\
\hline \multirow[t]{10}{*}{ Static culture } & C. cilicium & LS & 8 & 2 & 0 & 3 \\
\hline & & Modified MS & 10 & 0 & 0 & 4 \\
\hline & C. coum & Modified MS & 17 & 0 & 0 & 1 \\
\hline & C. graecum & LS & 14 & 0 & 0 & 3 \\
\hline & & Modified MS & 38 & 0 & 0 & 2 \\
\hline & C. persicum & LS & 1 & 0 & 0 & 0 \\
\hline & & Modified MS & 21 & 0 & 0 & 7 \\
\hline & C. purpurascens & LS & 17 & 0 & 5 & 4 \\
\hline & & Modified MS & 12 & 0 & 0 & 4 \\
\hline & C. rohlfsianum & LS & 15 & 0 & 0 & 5 \\
\hline \multirow[t]{4}{*}{ Liquid culture } & C. graecum & LS & 8 & 0 & 0 & 2 \\
\hline & C. persicum & LS & 1 & 0 & 0 & 0 \\
\hline & C. purpurascens & LS & 7 & 0 & 2 & 0 \\
\hline & & Modified MS & 1 & 0 & 1 & 0 \\
\hline
\end{tabular}

二極性の塊茎様体の形成を報告しており，この両者は区

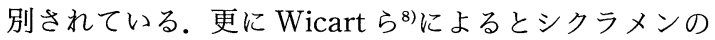
組織培養においては幾つかの形態形成経路が存在すると されている. 形態的観察から, 本実験でC. purpuras-

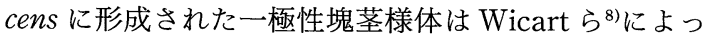
て示された形成経路の内, 根分裂組織の発達 $\rightarrow$ 塊茎の発 達 $\rightarrow$ 根のみ持つ一極性塊茎様体と言う経路を経て形成さ れたことが推察される.

\section{（3）不定根の形成}

C. persicum の体細胞胚誘導培地に移植したカルスの ほとんどは，いずれの培地上においても不定根を多数形 成した(Fig. 1C)。

以上のように, 体細胞胚形成, 体細胞胚の肥大に続く マイクロチューバー状の形態形成, 一極性塊茥様体形成 および不定根形成など，種により特異的と思われる体細 胞胚形成や形態形成が認められ，種によりホルモン条件

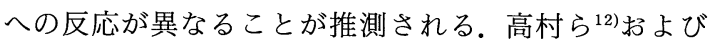
Takamura and Tanaka ${ }^{19)}$ も, 体細胞胚形成や不定器官 形成にはシクラメン園芸品種内の系統間でさえ差異があ ると報告している. シクラメンでは野生種, 園芸品種の いずれも種や系統によって体細胞肧形成や形態形成に多 少の差異が生ずると考えられる.

また，本実験において使用した二つの培地のうち， LS 培地は Otani and Shimada $(1991)^{14)}$ がシクラメン園 芸品種 ‘テーブル ミニ ライラックローズ’の葉身か らの体細胞肧誘導に成功した培地であり, 修正 MS 培 地は, 東京都農業試験場においてシクラメン野生種 $C$. purpurascens の葯培養からの体細胞胚誘導に成功した
培地である (渋沢：未発表)，本実験では葉柄および葉身 を用いたが，それぞれの培地におけるカルス形成率は種 により様々であり，一貫した傾向は認められなかった。 体細胞肧形成においては，培地間よりも外植体間で差異 が認められ(Table 3,4), 体細胞胚形成は培地成分より も種の能力に依存したものと考えられる.

本実験において種間における体細胞胚形成能などの違 いが調査されたとともに，C. cilicium, C. coum, C. graecum, C. rohlfsianum の 4 種において体細胞胚形成 に初めて成功した. 得られた体細胞肧およびマイクロ チューバーは植物育成培地上で現在育成中である (Fig. II, J).

\section{摘 要}

7 種の Cyclamen 野生種 (C. cilicium, C. coum, C. graecum, C. hederifolium, C. persicum, C. purpurascens, C. rohlfsianum)の成株から採取した葉柄および葉身を 外植体とし, カルス経由の体細胞胚誘導を試みた。 カル ス誘導には 2 種類の培地を用いた。一つは Linsmaier and Skoog (1965) ${ }^{23)}$ の培地に $1.0 \mathrm{mg} \bullet l^{-1} 2,4$-dichlorophenoxyacetic acid $(2,4-\mathrm{D}), 0.1 \mathrm{mg} \cdot l^{-1}$ kinetin, 50.0 $\mathrm{g} \cdot l^{-1}$ sucrose, および $2.0 \mathrm{~g} \cdot l^{-1}$ gellan gum を添加し たものである.もう一つは Murashige and Skoog $(1962)^{24)}$ の培地の主成分のうち, $\mathrm{NH}_{4} \mathrm{NO}_{3}, \mathrm{KNO}_{3}$, $\mathrm{CaCl}_{2} ・ 2 \mathrm{H}_{2} \mathrm{O}, \mathrm{MgSO}_{4} \cdot 7 \mathrm{H}_{2} \mathrm{O}$ および $\mathrm{KH}_{2} \mathrm{PO}_{4}$ の濃度を 半分にした修正 MS 培地に, $5.0 \mathrm{mg} \cdot l^{-1} 2,4-\mathrm{D}, 0.1$ $\mathrm{mg} \cdot l^{-1}$ kinetin, $60.0 \mathrm{~g} \cdot l^{-1}$ sucrose, $3.0 \mathrm{~g} \cdot l^{-1}$ gellan 
gum および $10.0 \%(\mathrm{v} / \mathrm{v})$ ココナッツミルクを添加したも のである. 形成されたカルスは，カルス誘導培地からそ れぞれのホルモンを除いた体細胞胚誘導培地へ移植し， 体細胞胚形成を促した。

C. hederifolium およびC. coum の葉身からはカルス は得られなかった。それ以外の種においてはカルス形成 が見られ，ほとんどの種において葉身よりも葉柄で高い カルス形成率が認められた。さまざまな色および形態の カルスが得られ，それは種に特異的であった。 $C$. cilicium のカルスのみ, カルス誘導培地上で, すでに体 細胞胚を形成した。 カルスをホルモンフリーの体細胞肧 誘導培地に移植した後, 体細胞肧形成 (C. cilicium, $C$. coum, C. graecum, おょび C. rohlfsianum), 体細胞胚 におけるマイクロチューバー状の肥大(C. graecum),

一極性塊茎様体形成 (C. purpurascens) および不定根の 形成 (C. persicum)などが認められた. C. hederifolium は, 最も低いカルス形成率を示し，ホルモンフリー培地 上でもカルス増殖や形態形成は全く認められなかった。

\section{謝辞}

本実験を行うに当たり，広島市植物公園と埼玉県農林 総合研究センター園芸支所の石坂宏博士より貴重なシク ラメン野生種を分譲していただいた。また，東京都農業 試験場の渋沢(小林)直恵氏と小川謙司氏（現 東京都庁） からは実験に関して大変有益なアドバイスを頂いた。こ れらのご協力に心より御礼申し上げる.

\section{引用文献}

1) Grey-Wilson, C.: Cyclamen. B. T. Batsford Ltd., London, pp. 1-192 (1997)

2) Ishizaka, H. and Uematsu, J. : Production of interspecific hybrids of Cyclamen persicum Mill. and $C$. hederifolium Aiton. by ovule culture, Japan J. Breed., 42 : 353-366 (1992)

3) Ishizaka, H. and Uematsu, J. : Interspecific hybrids of Cyclamen persicum Mill. and C. purpurascens Mill. produced by ovule culture, Euphytica, $82:$ 31-37 (1995)

4) Ishizaka, H. : Interspecific hybrids of Cyclamen persicum and C. graecum, Euphytica, 91: 109$117(1996)$

5）小林直恵，小川謙司：肧珠培養によるCyclamen persicum Mill.とC. rohlfsianum Aschers.および C. libanoticum Hildebr.の種間雑種作出, 育種学 雑誌，44 別冊 $2: 85$ (1994)

6) Geier, T. : Morphogenesis and plant regenera- tion from cultured organ fragments of Cyclamen persicum, Acta Horticulturae, 78 : 167-174 (1977)

7) Okumoto, H. and Takabayashi, S. : Aseptic culture of cyclamen tuber tissue, J. Japan Soc. Hort. Sci., 38 : 178-187 (1968)

8) Wicart, G., Mouras, A. and Lutz, A. : Histological study of organogenesis and embryogenesis in Cyclamen persicum Mill. tissue cultures: Evidence for a single organogenetic pattern, Protoplasma, 119: 159-167 (1984)

9) Wainwright, $\mathrm{H}$. and Harwood, A. C. : In vitro organogenesis and plant regeneration of Cyclamen persicum Mill. using seedling tissue, J. Hort. Sci., 60 : 397-403 (1985)

10） 三浦泰昌：シクラメン，樋口春三監修：植物組織 培養の世界, 柴田ハリオ硝子株式会社, pp. 171174 (1988)

11) Murasaki, K. and Tsurushima, H. :Improvement on clonal propagation of cyclamen in vitro by the use of etiolated petioles, Acta Horticulturae, 226 : 721-724(1988)

12）高村武二郎，筒井政道, 田中道男：シクラメン組 織培養における形態形成の品種間差異と $2,4-\mathrm{D}$ 添加培地を用いた不定芽形成，園芸学雑誌， 64 別冊 1: 530-531 (1995)

13) Takamura, T., Tsutsui, M. and Tanaka, M: Micropropagation of Yellow-flowered cyclamen through adventitious organogenesis in medium containing 2, 4-Dichlorophenoxyacetic acid, Tech. Bull. Fac. Agr. Kagawa Univ., 48 (1) : 33-38 (1996)

14) Otani, M. and Shimada, $T$ : Somatic embryogenesis and plant regeneration from Cyclamen persicum Mill. leaf cultures, Plant Tissue Culture Letters, 8 : 121-123(1991)

15） 大橋一夫，和久井 隆，米内貞夫：シクラメンの 組織培養による增殖 第 3 報 不定胚利用による増 殖，栃木県農業試験研究報告，39: 57-74 (1992)

16) Kiviharju, E., Tuominen, U. and Tormala, T. : The effect of explant material on somatic embryogenesis of Cyclamen persicum Mill, Plant Cell, Tissue and Organ Culture, 28: 187-194 (1992)

17）原田牧人, 遊佐吉雄: 不定胚によるシクラメン (ビクトリア)の大量増殖法, 宮城県農業センター 研究報告, 60 (1994)

18) Takamura, T., Miyajima, I. and Matsuo, E. : Somatic embryogenesis of Cyclamen persicum Mill. 'Anneke' from aseptic seedlings, Plant Cell Reports, 15 : 22-25(1995)

19) Takamura, T. and Tanaka, M. : Somatic embryogenesis from the etiolated petiole of cyclamen (Cyclamen persicum Mill.), Plant Tissue Culture Letters, 13 : 43-48(1996)

20) Kreuger, M., Postma, E., Brouwer, Y. and G. J. van Holst : Somatic embryogenesis of Cyclamen persicum in liquid medium, Physiol. Plant., 94 : 
605-612 (1995)

21) Wilnkelmann, T., Hohe, A. and Schwenkel, HG. : Establishing embryogenic suspension cultures in Cyclamen persicum 'Purple Flamed', Adv. Hort. Sci., 12 : 25-30(1998)

22) Karam, N. S. and Al-Majathoub, M. : In vitro shoot regeneration from mature tissue of wild Cyclamen persicum Mill, Scientia Horticulturae, $86: 323-333(2000)$

23) Linsmaier, E. M. and Skoog, F. : Organic growth factor requirements of tobacco tissue cultures, Physiol. Plant., 18 : 100-127 (1965)
24) Murashige, T. and Skoog, F. : A revised medium for rapid growth and bioassays with tabacco tissue cultures, Physiol. Plant., $15: 473$ -497 (1962)

25） 三浦泰昌, 尾上洋一, 北浦健生：シクラメンの生 育時期による污染微生物の変動と組織培養におけ る防除法について, 園芸学雑誌 58 別冊 2：516517 (1989)

26）小林直恵：組織培養によるシクラメン Cyclamen persicum Mill.塊茎梯体形成法, 東京都農業試験 場研究報告, 24 (1992) 